\title{
Case Report and Review of the Literature
}

\section{A Giant Pre-Peritoneal Lipoma: A Report of an Uncommon Presentation of a Rare Entity and a Review of the Literature}

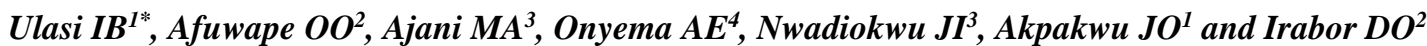 \\ ${ }^{l}$ Department of Surgery, University College Hospital, Ibadan, Nigeria \\ ${ }^{2}$ Division of Gastrointestinal Surgery, Department of Surgery, College of Medicine, University of Ibadan/University College Hospital, Ibadan, Nigeria \\ ${ }^{3}$ Department of Pathology, University College Hospital, Ibadan, Nigeria \\ ${ }^{4}$ Department of Radiology, University College Hospital, Ibadan, Nigeria
}

\section{A R T ICLE INFO}

Article history:

Received: 24 June, 2021

Accepted: 5 July, 2021

Published: NA

\section{Keywords:}

Giant

lipoma

pre-peritoneal

abdominal swelling

\begin{abstract}
A B S T R A C T
Background: A lipoma is one of the commonest benign tumors in surgical practice. Lipomas are usually found on the trunk and limbs but less commonly within the abdomen, where they occur frequently in the mesentery as well as the subserosa and submucous layer of the gastrointestinal tract. Pre-peritoneal lipomas are rare.

Case Presentation: A 44-year-old woman presented with a painless and progressive right-sided abdominal swelling of 5 months duration. Examination revealed a $16 \mathrm{~cm}$ x $14 \mathrm{~cm}$ slightly mobile and non-tender firmto-hard hour-glass-shaped mass extending from the right hypochondrial to right iliac and the suprapubic regions. Abdominal ultrasonography showed a $5 \mathrm{~cm} \times 6 \mathrm{~cm}$ bowel thickening in the right iliac fossa suggestive of an ileocecal mass while a computerized tomography showed a $20.8 \mathrm{~cm}$ x $6.3 \mathrm{~cm} \times 20.1 \mathrm{~cm}$ hypodense mass within the peritoneal cavity, extending from the epigastric region to the pelvis, anterior to the bowel loops and more to the right. At laparotomy, a huge, well encapsulated yellowish mass in the preperitoneal space, weighing $1,520 \mathrm{~g}$ was excised. Histology confirmed a lipoma.

Conclusion: A preperitoneal lipoma is an uncommon soft tissue tumor and the giant ones are extremely rare. Although a rare cause of a painless abdominal swelling, pre-peritoneal lipoma should be considered as a differential diagnosis in patients presenting with an unremarkable feature suggestive of an intra-abdominal pathology.
\end{abstract}

\section{Background}

Lipomas are benign tumors of mature adipose tissue commoner between the ages 40-60 years with a predilection for the male gender [1]. Lipomas may be solitary or multiple, superficial or deep in location and are usually painless. Painful lipomas may be multiple (Dercum's disease) or solitary in which case pain is usually due to a torsion. Superficial lipomas occur commonly in the trunk, head and neck regions and the limbs where cosmetic concerns or pain are indications for their removal. The relatively uncommon deep-seated lipomas occur in the thorax, retroperitoneum or abdominal cavity [2]. Intra-abdominal lipomas usually affect the omentum, mesentery, the submucosa and subserosa of the gastrointestinal tract [3]. Involvement of the preperitoneal layer of the anterior abdominal wall is rare with only 8 cases reported so far in the literature (Table 1) [4-11]. Sanchez et al. defined a giant lipoma as one that is at least $10 \mathrm{~cm}$ in diameter or at least $1000 \mathrm{~g}$ in weight [12]. Only 1 case of a giant lipoma of the parietal peritoneum (LPP) has been reported by Choi et al. [11]. Because of its rarity, we are presenting this case of preperitoneal abdominal lipoma. This case is reported in line with the SCARE criteria for case reports [13].

${ }^{*}$ Correspondence to: Dr. Ulasi Ikechukwu Bartholomew, Department of Surgery, University College Hospital, Ibadan, Nigeria; Tel: 08068263652; E-mail: batholy@yahoo.com 
Table 1: A summary of case reports on lipoma involving the parietal peritoneum.

\begin{tabular}{|c|c|c|c|c|c|c|c|c|c|c|c|}
\hline $\mathbf{s} / \mathbf{n}$ & $\begin{array}{l}\text { Author / } \\
\text { year }\end{array}$ & $\begin{array}{l}\text { Age / } \\
\text { gender }\end{array}$ & $\begin{array}{l}\text { Presenting } \\
\text { feature }\end{array}$ & $\begin{array}{l}\text { Possible } \\
\text { /stated Risk } \\
\text { factor }\end{array}$ & $\begin{array}{l}\text { Initial } \\
\text { diagnosis }\end{array}$ & Intra-op findings & $\begin{array}{l}\text { Procedure } \\
\text { (size) }\end{array}$ & \begin{tabular}{|l} 
Reported \\
largest size \\
( \& weight) of \\
lesion
\end{tabular} & $\begin{array}{l}\text { LOS } \\
\text { (days) }\end{array}$ & Histology & $\begin{array}{l}\text { Follow } \\
\text { up }\end{array}$ \\
\hline 1 & $\begin{array}{l}\text { Barut [4] / } \\
2006\end{array}$ & $67 y / F$ & $\begin{array}{l}\text { Acute } \\
\text { abdominal } \\
\text { pain x 4/7 }\end{array}$ & Obesity & NS & $\begin{array}{l}\text { Thin-walled soft } \\
\text { yellow mass from } \\
\text { the parietal } \\
\text { peritoneum onto } \\
\text { the median } \\
\text { umbilical ligament }\end{array}$ & $\begin{array}{l}\text { Complete } \\
\text { excision via } \\
\text { laparotomy }\end{array}$ & $6 \mathrm{~cm}(\mathrm{NS})$ & 2 & Lipoma & $1 \mathrm{yr}$ \\
\hline 2 & $\begin{array}{l}\text { Bunker [5] / } \\
2013\end{array}$ & $34 y / F$ & $\begin{array}{l}\text { Right iliac } \\
\text { fossa pain } x \\
3 / 7\end{array}$ & NS & $\begin{array}{l}\text {-Appendicitis } \\
\text {-Ovarian } \\
\text { pathology } \\
\text {-Renal colic }\end{array}$ & \begin{tabular}{|l|} 
Torted, \\
pedunculated, \\
parietal wall \\
lipoma in the right \\
iliac fossa + acute \\
hemorrhage; \\
normal appendix
\end{tabular} & $\begin{array}{l}\text { Laparosocpic } \\
\text { excision }+ \\
\text { Appendicectomy } \\
\\
\end{array}$ & NS (NS) & 1 & NS & NS \\
\hline 3 & $\begin{array}{l}\text { Shrestha [6] } \\
\text { / } 2014\end{array}$ & $32 y / M$ & $\begin{array}{l}\text { Right iliac } \\
\text { fossa pain } x \\
1 / 7\end{array}$ & NS & $\begin{array}{l}\text { Acute } \\
\text { Appendicitis }\end{array}$ & $\begin{array}{l}\text { Torted, } \\
\text { pedunculated } \\
\text { lipoma, } 3 \mathrm{~cm} \text { in size } \\
\text { on the right lower } \\
\text { parietal peritoneum }\end{array}$ & $\begin{array}{l}\text { Laparosocpic } \\
\text { excision }+ \\
\text { Appendicectomy }\end{array}$ & $3 \mathrm{~cm}$ (NS) & 3 & \begin{tabular}{|l|} 
Lobulated \\
adipose \\
tissue \\
Lympoid \\
hyperplasia \\
of appendix
\end{tabular} & NS \\
\hline 4 & $\begin{array}{l}\text { Sathyakrish } \\
\text { na [7] / } 2014\end{array}$ & $21 \mathrm{y} / \mathrm{F}$ & $\begin{array}{l}\text { Right lower } \\
\text { abdominal } \\
\text { pain x } 1 / 12\end{array}$ & NS & $\begin{array}{l}\text {-Appendicitis } \\
\text {-Ovarian } \\
\text { pathology } \\
\text {-Renal colic }\end{array}$ & $\begin{array}{l}\text { A torted, } \\
\text { pedunculated } \\
\text { lipoma in the right } \\
\text { lower quadrant of } \\
\text { the anterior } \\
\text { abdominal wall }\end{array}$ & $\begin{array}{l}\text { Laparoscopic } \\
\text { resection }\end{array}$ & NS (NS) & 1 & $\begin{array}{l}\text { Infarcted } \\
\text { lipoma }\end{array}$ & NS \\
\hline 5 & $\begin{array}{l}\text { Bang [8] / } \\
2014\end{array}$ & $75 y / M$ & $\begin{array}{l}\text { Right lower } \\
\text { abdominal } \\
\text { pain x } 1 / 52 \text {, } \\
\text { post right } \\
\text { hemicolecto } \\
\text { my }\end{array}$ & $\begin{array}{l}\text { Operative } \\
\text { trauma / } \\
\text { intra-op } \\
\text { adipose } \\
\text { tissue } \\
\text { seeding/ } \\
\text { high BMI }\end{array}$ & $\begin{array}{l}\text {-Epiploic } \\
\text { appendagitis } \\
\text {-Dermoid } \\
\text {-Lipoma } \\
\text {-Liposarcoma }\end{array}$ & $\begin{array}{l}\text { Large, soft, right } \\
\text { lower abdominal } \\
\text { wall mass; small } \\
\text { bowel adhesion }\end{array}$ & $\begin{array}{l}\text { Complete } \\
\text { excision }+ \\
\text { adhesiolysis via } \\
\text { laparotomy }\end{array}$ & $6.5 \mathrm{~cm}(\mathrm{NS})$ & NS & Lipoma & $>1 \mathrm{yr}$ \\
\hline 6 & $\begin{array}{l}\text { Salgaonkar } \\
{[9] / 2016}\end{array}$ & $79 y / M$ & $\begin{array}{l}\text { Left lower } \\
\text { abdominal } \\
\text { pain x 8/12 }\end{array}$ & NS & NS & $\begin{array}{l}\text { Large lipomatous } \\
\text { lesion apparently } \\
\text { arising in the } \\
\text { extraperitoneal } \\
\text { layer in the left } \\
\text { iliac fossa }\end{array}$ & $\begin{array}{l}\text { Complete } \\
\text { Laparosocpic } \\
\text { excision }+ \\
\text { cholecystetcomy }\end{array}$ & $6.3 \mathrm{~cm}(\mathrm{NS})$ & 1 & $\begin{array}{l}\text { Lipoma } \\
\text { Chronic } \\
\text { cholecystitis }\end{array}$ & $1 \mathrm{yr}$ \\
\hline 7 & $\begin{array}{l}\text { Özemir [10] } \\
\text { / } 2016\end{array}$ & $35 \mathrm{y} / \mathrm{F}$ & $\begin{array}{l}\text { Right lower } \\
\text { quadrant } \\
\text { abdominal } \\
\text { pain x } 2 / 7\end{array}$ & NS & $\begin{array}{l}\text { Acute } \\
\text { appendicitis }\end{array}$ & \begin{tabular}{|l|} 
Pre-peritoneal, \\
torsed and \\
gangreneous \\
lipoma in the right \\
lower quadrant \\
with $40 \mathrm{ml}$ of \\
reactive pericecal \\
fluid
\end{tabular} & $\begin{array}{l}\text { Laparoscopic } \\
\text { excision }\end{array}$ & $4 \mathrm{~cm}$ (NS) & 2 & Lipoma & NS \\
\hline 8 & $\begin{array}{l}\text { Choi [11]/ } \\
2018\end{array}$ & $36 / \mathrm{M}$ & $\begin{array}{l}\text { Urinary } \\
\text { frequency } x \\
6 / 12\end{array}$ & NS & NS & $\begin{array}{l}\text { A huge, mobile, } \\
\text { soft mass in the } \\
\text { external peritoneal } \\
\text { layer of the lower } \\
\text { abdomen }\end{array}$ & $\begin{array}{l}\text { Laparoscopic } \\
\text { excision with } \\
\text { preservation of } \\
\text { parietal } \\
\text { peritoneum }\end{array}$ & $22 \mathrm{~cm}(942 \mathrm{~g})$ & 6 & Lipoma & NS \\
\hline
\end{tabular}




\begin{tabular}{|l|l|l|l|l|l|l|l|l|l|l|}
\hline 9 & Present case 44 / F & $\begin{array}{l}\text { Painless } \\
\text { Abdominal } \\
\text { swelling } x \\
5 / 12\end{array}$ & Not known & $\begin{array}{l}\text { Ileocecal } \\
\text { tumor }\end{array}$ & $\begin{array}{l}\text { A giant, } \\
\text { pedunculated pre- } \\
\text { peritoneal mass } \\
\text { attached to the } \\
\text { midline; had soft } \\
\text { and firm areas and } \\
\text { weighed 1,520g }\end{array}$ & $\begin{array}{l}\text { Complete } \\
\text { excision }\end{array}$ & $\begin{array}{l}20.8 \mathrm{~cm} \\
(1,520 \mathrm{~g})\end{array}$ & 4 & Lipoma & $6 \mathrm{mo}$ \\
& & & & & & & \\
\hline
\end{tabular}

LOS: Length of Hospital Stay; NS: Not Stated.

\section{Case Presentation}

A 44-year-old woman presented with a painless but progressive rightsided abdominal swelling of 5 months duration. She had no history suggestive of gastrointestinal bleeding or change in bowel habit. There was no preceding history of abdominal trauma or previous abdominal surgery. She had no personal or family history of malignancies. Examination revealed a full abdomen with an hour-glass-shaped, nontender, slightly mobile mass extending from the right hypochondrial to right iliac regions and extending medially to the suprapubic region. It measured $16 \mathrm{~cm} \times 14 \mathrm{~cm}$. The mass was firm in consistency and extended below the pubic ramus. Vaginal and rectal examination findings were normal.

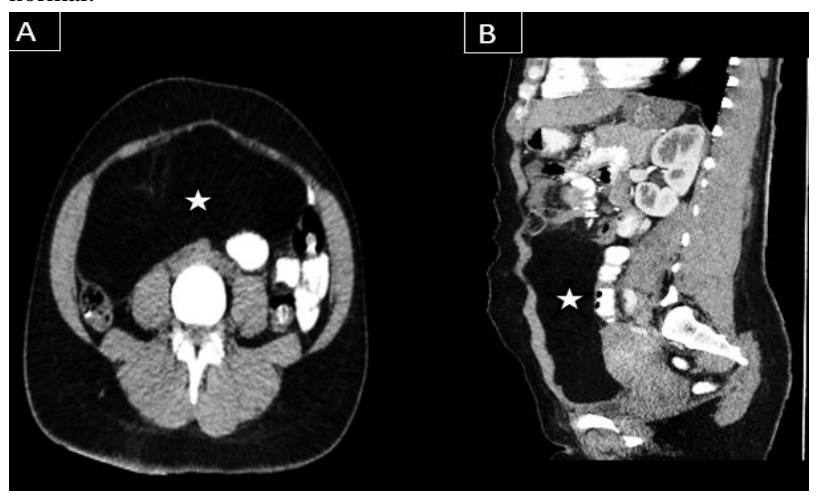

Figure 1: A) Axial computed tomography image of the abdomen taken at the level of the mid abdomen showing huge well-defined homogenous fat-density mass (star) deep to the anterior abdominal wall muscles. The mass is seen exerting some mass effect on the bowel loops. B) Sagittal computed tomography image of the abdomen showing the same mass (star) deep to the anterior abdominal wall muscles displacing the intraabdominal structures around it. No features of infiltration are seen.

An abdominal ultrasonography that showed a $5 \mathrm{~cm} \times 6 \mathrm{~cm}$ bowel thickening in the right iliac fossa suggestive of an ileocecal mass. A computerized tomography showed a $20.8 \mathrm{~cm} \times 6.3 \mathrm{~cm} \times 20.1 \mathrm{~cm}$ hypodense mass within the peritoneal cavity, extending from the epigastric region to the pelvis, anterior to the bowel loops and more to the right. It had multiple thin internal non-enhancing linear densities in keeping with fibrous septations (Figures 1A \& 1B). At exploratory, the findings were an encapsulated giant pre-peritoneal yellowish soft mass with a thin capsule attached to the umbilicus by a short stalk (Figure 2A). The parietal peritoneum which formed the capsule of the mass was opened (Figure 2B) and the mass was completely excised. The resected specimen (Figure 2C) weighed $1,520 \mathrm{~g}$ and measured $20 \mathrm{~cm} \mathrm{x} 6 \mathrm{~cm} \mathrm{x}$ $18 \mathrm{~cm}$. She was discharged home on the $4^{\text {th }}$ post-operative day. Histology of the resected specimen (Figures 3A \& 3B) showed a lipoma. She remains in good condition 6 months post-operatively.
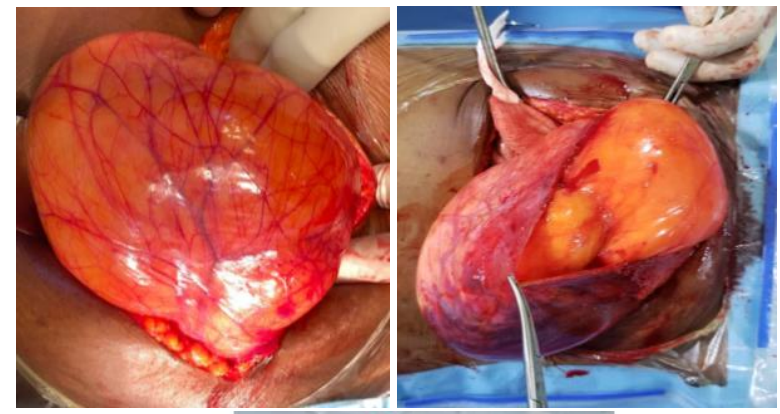

A

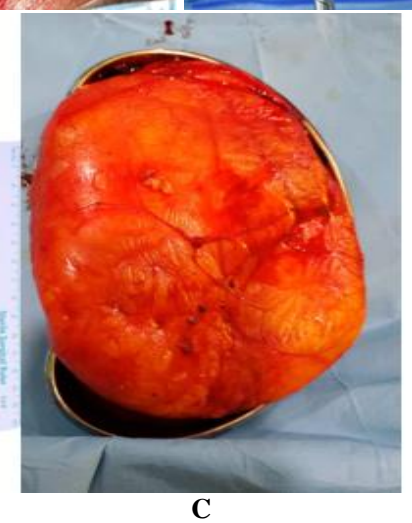

$\mathbf{B}$

C

Figure 2: Intra-operative findings: A) Mobilization of the giant mass. B) Opening of the thin capsule of the mass prior to excision. C) Resected specimen.
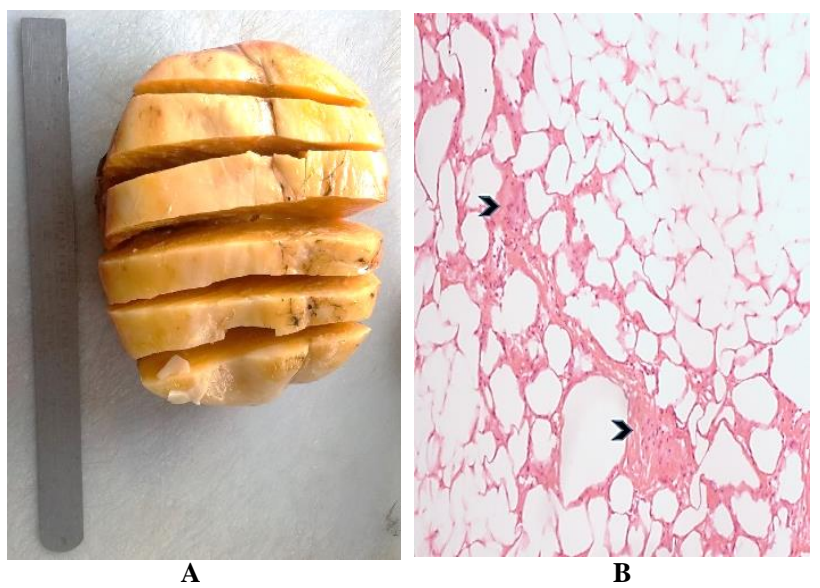

Figure 3: A) Gross appearance of specimen, B) H \& E stain at $x 400$ magnification showing lobules of mature adipocytes separated by intervening fibrous stroma (black arrow heads). 


\section{Discussion}

Lipomas are one of the commonest superficial lumps in surgical practice, especially the subcutaneous lipomas [14]. Deep-seated lipomas are unique in being obscure, at higher risk of malignant transformation and rare [15-17]. The incidence of LPP is rare with only 8 cases reported in the literature. Out of these, 7 cases presented with an abdominal pain while the remaining case presented with urinary frequency (Table 1). We had a case of a painless giant pre-peritoneal lipoma that presented with progressive abdominal swelling.

Although a slight predilection for males had been noted in the developed clime, recent studies done locally showed a slight female preponderance, similar to reports about 3 decades ago [18-21]. Lipomas are usually asymptomatic in nature. Patients only present when pain or cosmesis becomes a concern. This insidious nature of presentation makes them unnoticed especially when deep-seated, manifesting only when they grow big enough to cause pain or when there is a torsion of even a small but pedunculated lesion. Other patients had features of urinary frequency [11]. Our patient is the first where an obvious abdominal swelling was the only presenting feature of an LPP. Lipomas grow slowly over time except there is a malignant transformation. Yet the duration of symptom in our patient was just 5 months for a lesion that well qualifies as a giant lipoma. One explanation for this is the deep nature of the lesion and the fact that it was not torsed.

Whilst the diagnosis of superficial lipomas can be made clinically, that of deep-seated lipomas requires an extreme level of suspicion. Clinical manifestations depend on the size and location of mass. Symptoms are few or absent. Pain may be caused by partial or complete intestinal obstruction, torsion or volvulus. Ultrasonography depicts these intraabdominal lipomas as well-defined homogeneous, echogenic masses. Computed tomography depicts intraabdominal lipomas as masses with low attenuation like adipose tissue. In most cases, the diagnosis is made intra-operatively, as seen in the previous case reports, including ours. In this patient we considered a diagnosis of Ileocecal malignancy which is the commonest cause compared to other causes painless right-sided abdominal swelling (ileocecal tuberculosis, Crohn's disease, amoeboma, tubo-ovarian and renal pathology).

An important differential diagnosis of a lipoma is an atypical lipoma/well-differentiated liposarcoma which is known to possess similar features with a giant lipoma: they both have a variable consistency, are usually non-tender, and both show positivity for vimentin and S-100 protein on immunostaining [22]. Molecular testing has been recommended by Zhang et al. for relapsing lipomas, lipomas with cytologic atypia and large lipomatous tumors $(>15 \mathrm{~cm})$ without cellular atypia like ours [23]. However, molecular evaluation is not readily available in many developing countries. Hence, the possibility of these lesions being malignant, especially the deep-seated ones, should always be considered. Consequently, complete surgical excision of such lesions should be performed. This reduces the possibility of relapse, if the histopathological examination suggests a malignancy. To the best of our knowledge, the only case of a giant LPP in the literature was reported by Choi et al. which measured 22 x $16 \times 7.5 \mathrm{~cm}$ and weighed $942 \mathrm{~g}$ [11]. Our report is the second reported case of a giant LPP and the first with a weight of up to $1,520 \mathrm{~g}$.
It is noteworthy from the case reports under this review that adipose tissue tumors of the parietal peritoneum are usually pedunculated, situated in the right lower quadrant of the parietal peritoneum of the anterior abdominal wall, amenable to complete excision with good postoperative outcome and are usually benign. We postulate that the weight of the lipoma on the thin parietal peritoneum in supine position and the effect of gravity in erect position may explain the pedunculated nature and predilection of LPP for the lower abdomen respectively, but not the right-sided preponderance.

We recommend a uniform nomenclature for these lipomas in the vicinity of the parietal peritoneum. Most reporters of this surgical entity have used the term "lipoma of the parietal peritoneum" while the rest used the terms "parietal wall lipoma" and "preperitoneal lipoma" [4-11]. We propose the use of the term "preperitoneal lipoma" as used by Ozemir $e t$ $a l$. This is because the preperitoneal layer, otherwise called the endoabdominal or extraperitoneal fat is the deepest layer of the anterior abdominal wall overlying the parietal peritoneum. Since the tissue of origin of this lipoma is in this layer of the abdominal wall, and not the parietal peritoneum (which is just a layer of mesothelial cells), it would be more appropriate to associate its nomenclature with the anatomical tissue of origin.

\section{Conclusion}

A preperitoneal lipomas is an uncommon soft tissue tumor and the giant ones are extremely rare. Although a rare cause of a painless abdominal swelling, a pre-peritoneal lipoma should be considered as a differential diagnosis in patients presenting with an unremarkable feature suggestive of an intra-abdominal pathology.

\section{Author Contributions}

Each of the authors has significantly contributed to the design, data acquisition and analysis, data interpretation and final editing of the submitted manuscript.

\section{Ethical Approval}

Ethical Approval was obtained.

\section{Consent}

A written informed consent was obtained from the patient to report this case.

\section{Conflicts of Interest}

None.

\section{REFERENCES}

1. Primrose JN (1995) Soft tissue tumours. 3rd ed. F. M. Enzinger and S W. Weiss (eds). $284 \times 220 \mathrm{~mm}$. Pp. 1120. Illustrated. 1995. St Louis, Missouri: Mosby-Year-Book. £160. BJS (Br J Surg) 82: 1437-1437. 
2. Al Ali MHM, Salih AM, Ahmed OF, Kakamad FH, Mohammed SH et al. (2019) Retroperitoneal lipoma; a benign condition with frightening presentation. Int J Surg Case Rep 57: 63-66. [Crossref]

3. Özer M, Ulusoy S, Parlak Ö (2016) A Rare Location: A Giant Mesenteric Lipoma. Med J Islamic World Acad Sci 24: 24-26.

4. Barut I, Tarhan OR, Cerci C, Ciris M, Tasliyar E (2006) Lipoma of the parietal peritoneum: an unusual cause of abdominal pain. Ann Saudi Med 26: 388-390. [Crossref]

5. Bunker DLJ, Ilie VG, Halder TK (2013) Torsion of an abdominal-wall pedunculated lipoma: a rare differential diagnosis for right iliac fossa pain. Case Rep Surg 2013: 587380. [Crossref]

6. Shrestha BB, Karmacharya M (2014) Torsion of a lipoma of parietal peritoneum: a rare case mimicking acute appendicitis. J Surg Case Rep 2014: rju062. [Crossref]

7. Sathyakrishna BR, Boggaram SG, Jannu NR (2014) Twisting lipoma presenting as appendicitis-a rare presentation. J Clin Diagn Res 8: ND07-ND08. [Crossref]

8. Bang CS, Kim YS, Balik GH, Han SH (2014) A case of lipoma of parietal peritoneum causing abdominal pain. Korean J Gastroenterol 63: 369-372. [Crossref]

9. Salgaonkar HP, Behera RR, Katara AN, Bhandarkar DS (2016) Laparoscopic excision of a lipoma of parietal peritoneum. J Minim Access Surg 12: 196-197. [Crossref]

10. Özemir IA, Orhun K, Bilgiç C, Eren T, Bayraktar B et al. (2016) [Torsion of a preperitoneal pedunculated lipoma of anterior abdominal wall mimicking acute appendicitis.] Ulus Travma Acil Cerrahi Derg 22: 502-504. [Crossref]

11. Choi H, Ryu D, Choi JW, Xu Y, Kim Y (2018) A giant lipoma of the parietal peritoneum: Laparoscopic excision with the parietal peritoneum preserving procedure - a case report with literature review. BMC Surg 18: 49. [Crossref]

12. Sanchez MR, Golomb FM, Moy JA, Potozkin JR (1993) Giant lipoma: case report and review of the literature. J Am Acad Dermatol 28: 266268. [Crossref]
13. Agha RA, Borrelli MR, Farwana R, Koshy K, Fowler AJ et al. (2018) The SCARE 2018 statement: Updating consensus Surgical CAse REport (SCARE) guidelines. Int J Surg 60: 132-136. [Crossref]

14. Ndukwe KC, Ugboko VI, Somotun G, Adebiyi KE, Fatusi OA (2003) A clinicopathological study of lipomas of the head and neck. Nig J Surg Res 5: 12-17.

15. Hwang J, Jo WM, Min BJ, Shin JS (2015) Deep-seated intramuscular lipoma penetrates the intercostal muscle. J Thorac Dis 7: E493-E495. [Crossref]

16. Farfour AN, AbuOmar NA, Alsohaibani FI (2020) Large lipoma of the ascending colon: a case report and review of literature. J Surg Case Rep 2020: rjaa354. [Crossref]

17. Amundson JR, Straus D, Azab B, Liu S, Buitrago MTG et al. (2018) Giant symptomatic gastric lipoma: A case report and literature review. Int J Surg Case Rep 51: 313-317. [Crossref]

18. Kanojia D, Dakle P, Mayakonda A, Parameswaran R, Puhaindran ME et al. (2019) Identification of somatic alterations in lipoma using whole exome sequencing. Sci Rep 9: 14370. [Crossref]

19. Mohammed U, Samaila MO, Abubakar M (2014) Pattern of adipose tissue tumors in Ahmadu Bello Universty Teaching Hospital, Zaria, Nigeria. Ann Niger Med 8: 8-10.

20. Mbah N, Abubakar U (2007) Subcutaneous lipomata in Sokoto, Nigeria: a 4-year review. Ann Afr Med 6: 84. [Crossref]

21. Rydholm A, Berg NO (1983) Size, site and clinical incidence of lipoma. Factors in the differential diagnosis of lipoma and sarcoma. Acta Orthop Scand 54: 929-934. [Crossref]

22. Ferraro GA, Salzillo R, De Francesco F, D'Andrea F, Nicoletti G (2015) Approach and management of a giant lipoma in the left lumbar region. Int J Surg Case Rep 14: 189-193. [Crossref]

23. Zhang H, Erickson Johnson M, Wang X, Oliveira JL, Nascimento AG et al. (2010) Molecular testing for lipomatous tumors: critical analysis and test recommendations based on the analysis of 405 extremity-based tumors. Am J Surg Pathol 34: 1304-1311. [Crossref] 